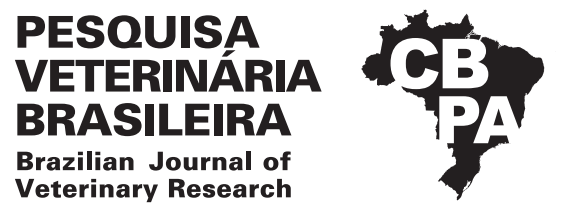

Pesq. Vet. Bras. 39(6):416-418, June 2019 DOI: 10.1590/1678-5150-PVB-6184

Original Article

ISSN 0100-736X (Print)

ISSN 1678-5150 (Online)

\title{
Fatal hemothorax caused by pleural mesothelioma in a lion ${ }^{1}$
}

\author{
Paulo Ricardo D. Rocha ${ }^{2,3}$, Roberta P. Duarte ${ }^{3}$ (D) Maria Gisela Laranjeira ${ }^{3}$, \\ Tawane Agda L. Melo ${ }^{3}$ (D), Eustaquio Z. Azevedo ${ }^{4}$, Sergio D. Garcia ${ }^{3}$ \\ and Gisele F. Machado ${ }^{3 *}$
}

\begin{abstract}
Rocha P.R.D., Duarte R.P., Laranjeira M.G., Melo T.A.L., Azevedo E.Z., Garcia S.D. \& Machado G.F. 2019. Fatal hemothorax caused by pleural mesothelioma in a lion. Pesquisa Veterinária Brasileira 39(6):416-418. Faculdade de Medicina Veterinária, Universidade Estadual Paulista "Julio de Mesquita Filho", Rua Clóvis Pestana 793, Dona Amélia, Araçatuba, SP 16050-680, Brazil. E-mail: giselem@fmva.unesp.br

Mesothelioma is considered a malignant neoplasm caused by the proliferation of mesothelial cells mostly from the pleura, peritoneum and pericardium. Here we described a case of fatal hemothorax caused by pleural mesothelioma in a lion by means of necropsy, histopathology and immunohistochemistry. Gross inspection of the thoracic cavity showed hemothorax with about 4 liters of blood. Microscopically, numerous, randomly distributed, soft, red-pink, irregular masses with up to $1 \mathrm{~cm}$ in diameter were observed in both visceral and parietal pleurae. Microscopically, a papillary structure pattern was observed in the thoracic masses, composed mainly by one layer of cubic mesothelial cells, which presented eosinophilic cytoplasm, central nucleus and evident nucleolus, supported by a low cellular fibrovascularstroma. Neoplastic cells were positive for both cytokeratin and vimentin by immunohistochemistry. This seems to be the first report of fatal hemothorax caused by pleural mesothelioma in a lion.
\end{abstract}

INDEX TERMS: Hemothorax, pleural mesothelioma, immunohistochemistry, Panthera leo, lion, mesothelioma, zoo animal, wildlife animals, pathology.

\begin{abstract}
RESUMO.- [Hemotórax fatal causado por mesotelioma pleural em um leão.] 0 mesotelioma é considerado um neoplasma maligna causada pela proliferação de células mesoteliais, principalmente da pleura, peritôneo e pericárdio. 0 presente caso descreve os achados macroscópicos, microscópicos e imuno-histoquímicos do hemotórax fatal causado por um mesotelioma pleural em um leão. Macroscopicamente, na cavidade torácica, foi observado cerca de 4 litros de sangue. Além disso, foram observadas numerosas massas macias, vermelho-rosa, irregulares, com até $1 \mathrm{~cm}$ de diâmetro e distribuídas aleatoriamente pelas pleuras parietal e visceral. Microscopicamente, as massas torácicas apresentavam estruturas
\end{abstract}

\footnotetext{
${ }^{1}$ Received on November 7, 2018.

Accepted for publication on February 15, 2019.

${ }^{2}$ Centro de Pesquisas, Universidade Paulista (Unip), Avenida José Maria Whitaker 290, São Paulo, SP 04057-000, Brazil.

${ }^{3}$ Faculdade de Medicina Veterinária, Universidade Estadual Paulista "Julio de Mesquita Filho" (Unesp), Rua Clóvis Pestana 793, Dona Amélia, Araçatuba, SP 16050-680, Brazil. *Corresponding author: giselem@fmva.unesp.br

${ }^{4}$ Zoológico Municipal de Araçatuba, Rua do Fico s/n, São Joaquim, Araçatuba, SP 16050-387.
}

papilares, compostas por uma camada de células mesoteliais, que apresentavam citoplasma eosinofílico, núcleo central e nucléolo evidente, suportada por um estroma fibrovascular pouco celular. A imuno-histoquímica foi positiva para ambas citoqueratina e vimentina nas células neoplásicas. Este trabalho descreve o que parece ser o primeiro relato de um hemotórax fatal causado por um mesotelioma pleural em um leão.

TERMOS DE INDEXAÇÃO: Hemotórax, imuno-histoquímica, Panthera leo, leão, mesotelioma pleural, animais de zoológico, animais silvestres, patologia.

\section{INTRODUCTION}

Mesothelioma is a cancer that arises from mesothelial cells of the pleura, peritoneum and pericardium, and occasionally from the tunica vaginalis testis (Gibbs \& Berry 2008, Bollo et al. 2011). This tumor can have a localized to more diffuse distribution and may present as multiple to coalescing nodular, and sessile to more pedunculated structures (Head et al. 2002). Mesothelioma is rare in all species but has been recorded most frequently in humans, especially associated with exposure to 
asbestos and erionite (Gibbs \& Berry 2008, Bollo et al. 2011) and it has also been experimentally induced in laboratory rodents, primates and dogs by exposure to asbestos fibers (Bollo et al. 2011). Mesothelioma is more frequent in cattle and dogs, but has been occasionally reported in horses, cats, pigs, a mouse and a goat (Krametter et al. 2004, Stoica et al. 2004, Brown et al. 2007). Although there is one description of pleural mesothelioma in a lion (Bollo et al. 2011), so far there is no association of this neoplasm with hemothorax in wild or domestic cats. The present case described a fatal hemothorax caused by pleural mesothelioma in a lion by means of necropsy, histopathology and immunohistochemistry.

\section{CASE REPORT AND DISCUSSION}

A 25 year old, male lion (Panthera leo), kept in a Zoo was referred for necropsy because of sudden death. The day before, the animal presented apathy, anorexia, dyspnea and an episode of emesis. On necropsy, the animal was in good body condition but markedly dehydrated. Oral and ocular mucosae were markedly pale. Numerous randomly distributed, soft, red-pink, irregular masses with up to $1 \mathrm{~cm}$ in diameter were observed in both visceral and parietal pleurae. The thoracic cavity contained approximately 4 liters of blood hemothorax
(Fig.1A). No masses were observed outside the thoracic cavity. Marked, diffuse emphysema was observed in the left lungs (Fig.1), whereas the right side was diffusely firm, dark-redand hemorrhagic (post-mortem hypostasis, figure not shown). No significant lesions were observed in other organs. Fresh samples of the thoracic masses, lungs, heart, brain, spinal cord, duodenum, liver and kidneys were fixed in $10 \%$ buffered formalin. Subsequently, tissues were routinely processed, embedded in paraffin and $4 \mu \mathrm{m}$ tissue sections were cut for histopathologic and immunohistochemical (IHC) evaluations. The sections for histopathology were stained with hematoxylin and eosin (HE).

Microscopically, the masses in the thoracic cavity had a papillary structure, composed mainly by one layer of cubic mesothelial cells, which presented eosinophilic cytoplasm, central nucleus and evident nucleolus, supported by a low cellular fibrovascular stroma, with a marked amount of collagen (Fig.1B). Mitosis or vascular invasion was absent. Marked emphysema, hyperemia, atelectasis and congestion were observed in the left lung. Erythrocytes in the bronchiolar lumen were observed, whereas in the right lungs, diffuse post-mortem hydrostatic congestion was present.
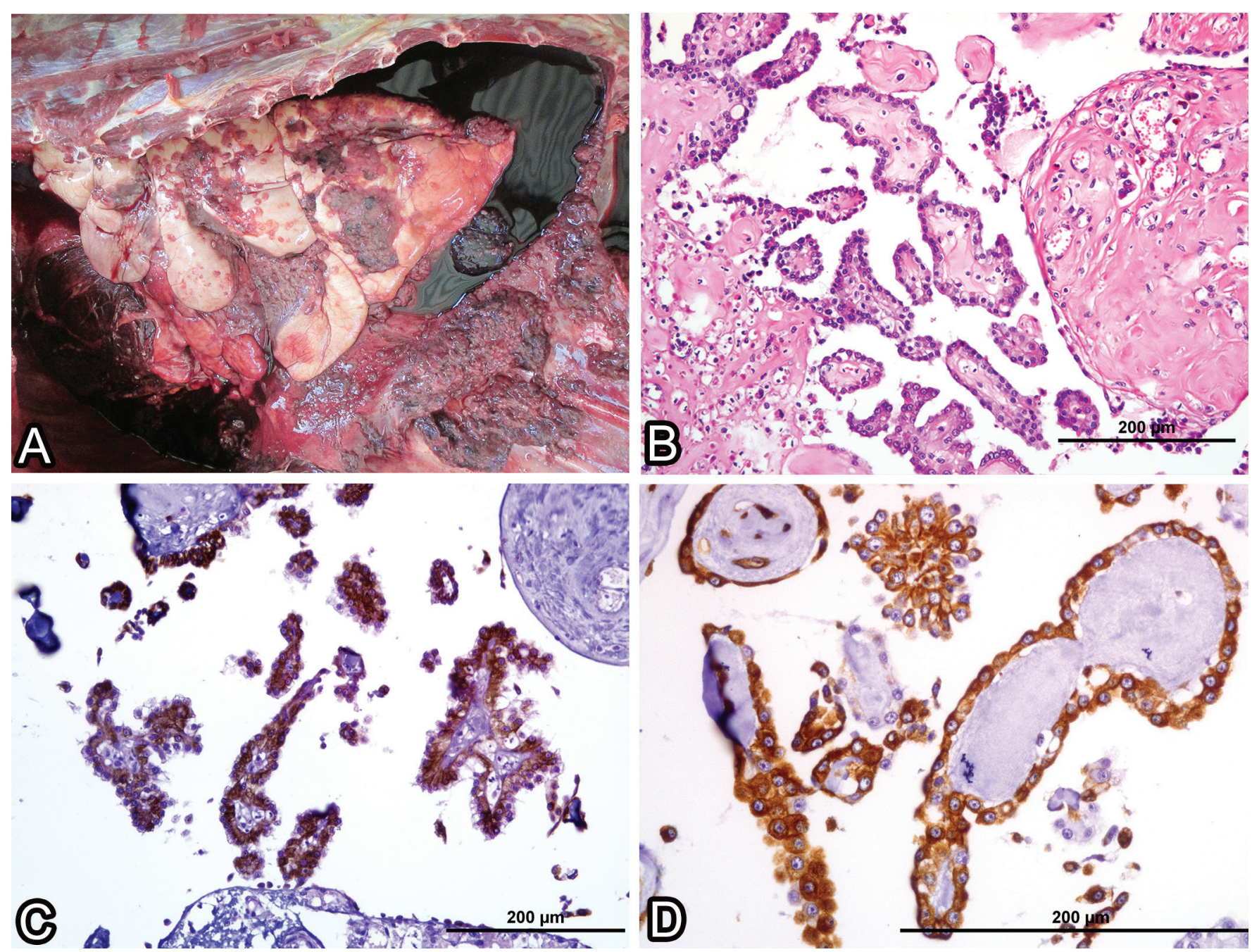

Fig.1. (A) Thoracic cavity and lungs. Mesothelioma in a lion (Panthera leo). Multifocal, soft, red-pink, irregular masses with up to $1 \mathrm{~cm}$ in diameter in both visceral and parietal pleurae, associated with hemothorax. (B) Lungs, mesothelioma. Papillary mass, composed mainly by one layer of cubic mesothelial cells, supported by a low cellular fibrovascular stroma. HE, bar $=200 \mu \mathrm{m}$. (C) Mesothelioma, cytoplasmic staining for cytokeratin in mesothelial neoplastic cells. IHC, bar $=200 \mu \mathrm{m}$. (D) Mesothelioma, cytoplasmic immunolabeling for vimentin in mesothelial neoplastic cells. IHC, bar $=200 \mu \mathrm{m}$. 
Sections of thoracic masses were submitted for immunohistochemical analysis with anti-cytokeratin and anti-vimentin antibodies using commercial immunohistochemical kits. Briefly, indirect immunohistochemistry was performed using monoclonal primary antibodies against cytokeratin (DAKO, Carpinteria, USA, Code M3515, 1:200) and vimentin (DAKO, Code M7020, 1:100). For antigen retrieval, all sections were incubated in citrate buffer $(\mathrm{pH} 6.0)$ at $125^{\circ} \mathrm{C}$ for $10 \mathrm{~min}$. The secondary detection system was a polymer LSAB2-HRP kit (Code K0679, DAKO, USA) was applied. Subsequently, all tissue sections were incubated with3,3'-diaminobenzidine chromogen (DAB, DAKO, USA) for $1 \mathrm{~min}$ at room temperature. Finally, the sections were counterstained using Mayer's hematoxylin. Positive controls included a mammary carcinoma and normal lung from two cats, respectively. Sections of the neoplasm herein described and the positive controls without the incubation of each primary antibody were used as negative controls. The cytoplasm of mesothelial cells was positive for both cytokeratin and vimentin (Fig.1B-C); the supportive connective tissue cells were also positive for vimentin (Fig.1D).

The gross and histologic findings in the lion of the present report were consistent with pleural mesothelioma. The diagnosis was confirmed by the immunolabeling of neoplastic cells for cytokeratin and vimentin. Immunohistochemical detection of both vimentin and cytokeratin are useful in distinguishing mesotheliomas from other epithelial or non-epithelial neoplasms (Brown et al. 2007). In domestic animals, mesothelioma is notable because it occurs most frequently as a congenital neoplasm in fetal or young cattle. In pigs, mesotheliomas are particularly more frequent as pleural, whereas in cattle they are more peritoneal (Krametter et al. 2004, Stoica et al. 2004, Brown et al. 2007). In wild cats, pleural mesotheliomas have been described in tigers (Panthera tigris) (Wiedner et al. 2008), leopards (Neofelis nebulosa) (Cunningham \& Dhillon 1998), and a lion (Bollo et al. 2011). Even though metastasis were not observed in the present case, pleural mesothelioma may spread and implants within the pleural cavity to cause persistent thoracic effusion, and often invades the underlying tissue or reaches the abdominal cavity via lymphatics vessels (Caswell \& Williams 2007). Moreover, pleural and peritoneal mesotheliomas can have a multicentric origin, and transcoelomic implantation with invasion of the underlying tissue is possible, although distant metastasis can seldom be found (Stoica et al. 2004).

Respiratory insufficiency associated with hypovolemic shock due to the massive hemothorax was most likely the causes of the death of this lion. Hemothorax is rare in human medicine and typically involves rupture of intrathoracic masses or underlying vascular pathology such as an aneurysm (Martinez et al. 1992). Bleeding associated with thoracic neoplasm has been attributed to several mechanisms, including: 1) direct exsanguination of the tumor into the pleural space, 2) acute bleeding due to rupture of the primary tumor, and 3) tumor invasion into larger vessels including arteries, causing vascular lesions (Nakamura et al. 2008, Snaebjornsson et al. 2011). In humans, spontaneous neoplasm-associated hemothorax has most commonly been associated with neurofibromatosis type 1, pseudomesotheliomatous carcinomas, angiosarcoma, hepatocellular carcinoma and lung carcinoma, the latter an uncommon cause of hemothorax (Snaebjornsson et al. 2011). In dogs, traumatic injuries and coagulopathies have been described as the most common causes of hemothorax. Dirofilaria immitis, Spirocerca lupi, hemangiosarcoma, mesothelioma, lung lobe torsion and pancreatitis may be other causes of hemothorax in dogs, even though the two latter are less commonly reported (Nakamura et al. 2008). To the best of the authors' knowledge, there are no descriptions of pleural mesothelioma associated with hemothorax in domestic or wild felids.

The differential diagnosis for pleural mesothelioma should include metastatic carcinomas, adenocarcinomas with diffuse peritoneal involvement and sarcomas (Stoica et al. 2004, Caswell \& Williams 2007). In the abdominal cavity, mesothelioma must be differentiated from peritoneal tuberculosis, peritoneal metastases from other tumors, and bacterial and parasitic granulomas (Krametter et al. 2004).

No microscopic evidence of bacterial, parasitic or a different type of neoplasm was observed in the lion of the present case. In conclusion, this seems to be the first report of fatal hemothorax caused by pleural mesothelioma in a lion.

Conflict of interest statement- The authors have no competing interests.

\section{REFERENCES}

Bollo E., Scaglione F.E., Tursi M., Schröder C., Degiorgi G., Belluso E., Capella S. \& Bellis D. 2011. Malignant pleural mesothelioma in a female lion (Panthera leo). Res. Vet. Sci. 91(1):116-118. <http://dx.doi.org/10.1016/j. rvsc.2010.08.005><PMid:20846704>

Brown C.C., Baker D.C. \& Barker I.K. 2007. Alimentary system, p.1-294. In: Maxie M.G. (Ed.), Jubb, Kennedy and Palmer's Pathology of Domestic Animals. Vol.2. 5th ed. Elsevier, New York.

Caswell J.L. \& Williams K.J. 2007. Respiratory system, p.523-578. In: Maxie M.G. (Ed.), Jubb, Kennedy and Palmer's Pathology of Domestic Animals. Vol.2. 5th ed. Elsevier, New York.

Cunningham A.A. \& Dhillon A.P. 1998. Pleural malignant mesothelioma in a captive clouded leopard (Neofelis nebulosa). Vet. Rec. 143(1):22-24. <http://dx.doi.org/10.1136/vr.143.1.22><PMid:9698630>

Gibbs G.W. \& Berry G. 2008. Mesothelioma and asbestos. Regul. Toxicol. Pharmacol. 52 (Suppl. 1):223-231. <http://dx.doi.org/10.1016/j. yrtph.2007.10.003> <PMid:18022298>

Head K.W., Else R.W. \& Dubielzig R.R. 2002. Tumours of the alimentary tract, p.401-481. In: Meuten D.J. (Ed.), Tumours in Domestic Animals. 4th ed. Iowa State Press, Ames, Iowa.

Krametter R., Bago Z., Floeck M. \& Baumgartner W. 2004. Abdominal mesothelioma in a goat. N.Z. Vet. J. 52(5):293-296. <http://dx.doi.org/1 0.1080/00480169.2004.36442><PMid:15768126>

Martinez F.J., Villanueva A.G., Pickering R., Becker F.S. \& Smith D.R. 1992. Spontaneous hemothorax: report of 6 cases and review of the literature. Medicine 71(6):354-368. <http://dx.doi.org/10.1097/00005792199211000-00003><PMid:1435230>

Nakamura R.K., Rozanski E.A. \& Rush J.E. 2008. Non-coagulopathic spontaneous hemothoraxin dogs. J. Vet. Emerg. Critical Care 18(3):292-297. <http:// dx.doi.org/10.1111/j.1476-4431.2008.00306.x>

Snaebjornsson P., Vos C.G., Hartemink K.J., Lely R.J., Samii S.M., Grünberg K. \& Paul M.A. 2011. Fatal hemothorax caused by pseudomesotheliomatous carcinoma of the lung. Pathol. Res. Int. 2011:836054. <http://dx.doi. org/10.4061/2011/836054><PMid:21789266>

Stoica G., Cohen N., Mendes O. \& Kim H.T. 2004. Use of immunohistochemical marker calretinin in the diagnosis of a diffuse malignant metastatic mesothelioma in an equine. J. Vet. Diagn. Invest. 16(3):240-243. <http:// dx.doi.org/10.1177/104063870401600313> <PMid:15152842>

Wiedner E.B., Isaza R., Lindsay W.A., Case A.L., Decker J. \& Roberts J. 2008. Pericardial mesothelioma in a Bengal tiger (Panthera tigris). J. Zoo Wildl. Med. 39(1):121-123. <http://dx.doi.org/10.1638/2007-0080.1> <PMid:18432108> 